\title{
Tempo e narrativa no gênero charge: condensar para potencializar
}

\author{
Eveline Coelho Cardoso*
}

Glayci Kelli Reis da S. Xavier ${ }^{* *}$

\section{Introdução}

\begin{abstract}
O ato de contar histórias está enraizado no comportamento social dos grupos humanos - antigos e modernos. As histórias são usadas para ensinar o comportamento dentro da comunidade, discutir morais e valores, ou para satisfazer curiosidades. Elas dramatizam relações sociais e os problemas de convívio, propagam ideias ou extravasam fantasias. Contar uma história exige habilidade.
\end{abstract}

Will Eisner, 2005.

O desenho é uma das mais antigas formas de expressão do homem. Desde a PréHistória, o homem primitivo fazia registros na parede das cavernas. Além disso, as narrações criadas por meio de imagens apareciam desde a Antiguidade, em tapeçarias, painéis pintados ou em alto-relevo, mosaicos, vitrais etc., e seu objetivo "não era apenas decorativo, mas também, e principalmente, registrar acontecimentos ou reforçar mitologias e crenças religiosas” (Feijó, 1997, p. 14).

Já nos dias de hoje, as histórias em quadrinhos, também conhecidas como HQs, bandas desenhadas, comics ou simplesmente gibis, configuram-se como narrativas extremamente populares em todo o planeta. Will Eisner (2010, p. Ix), famoso desenhista norte-americano, define as histórias em quadrinhos como uma arte sequencial, ou seja, uma "forma artística e literária que lida com a disposição de figuras ou imagens e palavras para narrar uma história ou dramatizar uma ideia”. Ao contar uma história, os quadrinhos utilizam linguagem própria e mecanismos peculiares para representar os elementos narrativos.

\footnotetext{
Doutora em Estudos de Linguagem pela Universidade Federal Fluminense (UFF). Professora de Língua Portuguesa e Literatura do Centro Federal de Educação Tecnológica Celso Suckow da Fonseca (CEFET/RJ), Nova Friburgo, RJ, Brasil.E-mail: eveline.cardoso@outlook.com.

** Doutora em Estudos de Linguagem pela Universidade Federal Fluminense (UFF). Professora Adjunta de Língua Portuguesa da Universidade Federal Fluminense (UFF), Niterói, RJ, Brasil. E-mail: glaycikelli@id.uff.br.
} 
Considerando o termo "história em quadrinhos" um "hipergênero" que agrega diferentes modos de produção, cada um com suas peculiaridades, apesar das semelhanças (RAmOs, 2010, p. 20), o gênero de quadrinhos que nos servirá como objeto de estudo neste trabalho é a charge, texto associado ao contexto jornalístico e muito conhecido por sua intenção humorística. A perspectiva adotada em nossa abordagem é a da análise do discurso semiolinguística (CHARAUDEAU, 1992; 1995; 2009), que nos leva a tratar a charge como produto do discurso midiático, no qual as diversas instâncias de produção buscam, basicamente, informar um evento, fornecendo ao leitor uma abordagem pessoal e crítica (CHARAUdEAU, 2010). Dessa forma, para além do interesse midiático básico de informar, próprio das mídias, o chargista tem liberdade para explorar mecanismos favoráveis à visada de captação de seu público.

"Charge", do francês charger, significa "carregar, atacar violentamente", o que já dá o tom dessas crônicas verbo-visuais nascidas no universo jornalístico ilustrado dos séculos XVIII e XIX. No mundo contemporâneo, imerso em tecnologias digitais de informação, as charges extrapolaram seu contexto original impresso e vêm ganhando outros suportes, sendo cada vez mais replicadas em inúmeras páginas e redes sociais, onde atingem um público incalculável.

A conquista de espaços que permitem à charge se perpetuar para além do circunstancial que lhe é inerente deve-se à facilidade com que promove a identificação do leitor, convidando-o a compartilhar suas fantasias transgressoras (TeIXeIRA, 2005). Esse convite verbo-visual está ancorado em diversos recursos formais e discursivos que potencializam a captação das charges, culminando em efeitos de humor e ironia, que são marcas registradas do gênero, como citamos.

Na pesquisa que ora se apresenta, intentamos, pois, descrever de que maneira a organização narrativa pode servir ao propósito comunicativo das charges, funcionando como um mecanismo importante na produção de seus efeitos de sentido. Os textos que nos servem como corpus são seis peças de cartunistas brasileiros que tematizam, em seu traço-texto, o rompimento da barragem de rejeitos de minério situada na cidade de Brumadinho (Minas Gerais, Brasil), de propriedade da mineradora multinacional brasileira Vale, ocorrido em 25 de janeiro de 2019.

Segundo o portal de notícias $\mathrm{G}_{1}{ }^{1}$ as barragens de rejeitos de minério de ferro são estruturas construídas para armazenar resíduos quando ocorre a separação entre o material com valor econômico e o rejeito, que não tem demanda de mercado. A barragem da mineradora Vale que rompeu em Brumadinho usava uma tecnologia denominada "montante", construção bastante comum nos projetos de mineração iniciados nas últimas décadas, mas considerada por especialistas uma opção menos segura e mais propensa a acidentes. Inclusive, essa era a mesma tecnologia utilizada na barragem de Mariana, que rompeu três anos antes do acontecimento.

1 Disponível em: https://g1.globo.com/economia/noticia/2019/o1/28/entenda-como-funciona-abarragem-da-vale-que-se-rompeu-em-brumadinho.ghtml. Acesso em: 31 out. 2019. 
No Brasil, segundo os dados disponíveis no site da Agência de Nacional de Mineração (ANM), existem hoje no país 839 barragens de mineração, sendo que 61 também são do tipo montante e 41 destas estão em Minas Gerais. Na tragédia de Brumadinho, estima-se que cerca de 12 milhões de metros cúbicos de lama de rejeitos tenham vazado do reservatório, que cobriram a cidade de uma camada de até 15 metros de profundidade em alguns pontos, configurando uma tragédia humana e ambiental de grande impacto. ${ }^{2}$

\section{O gênero charge sob a perspectiva semiolinguística}

As charges são um gênero gráfico de cunho humorístico ou irônico, marcado pela ancoragem em um fato específico, contemporâneo do chargista, o que pode acabar, em algumas situações, se tornando um desafio para os leitores do futuro. É esse aspecto, inclusive, que é usado para diferenciar a charge de outros gêneros, como o cartum, por exemplo, cuja temática é atemporal e universal, ou da caricatura, que se prende a determinada personalidade conhecida.

Constituindo-se de um texto verbo-visual (ou apenas visual) disposto em pequenos quadros, divididos sequencialmente ou não, a charge, como os demais gêneros do domínio jornalístico, procura retratar fatos e situações do domínio cultural, esportivo, político etc., contemporâneos de um determinado público. Tratase de um gênero marcadamente temporal e circunstancial, de cujo contexto é preciso ter conhecimento para que se consiga interpretar adequadamente.

Mas, para além do compromisso com um ideal de "realidade" e a "credibilidade" próprio das mídias, a charge busca construir uma representação particular dos fatos, dando a conhecer uma visão subjetiva do mundo pela maneira como representa, pelo viés do humor e da ironia, personagens reais ou tipos socialmente reconhecíveis (Nery, 2001). No dizer de Teixeira (2005, p. 13), considerando-se a ligação da charge aos fatos noticiados no domínio jornalístico, pode-se afirmar que esta não produz outra notícia, mas a mesma, com subjetividade e parcialidade, temperando a monotonia e a severidade do texto verbal jornalístico com a permissividade de um discurso que "diz o que o verbo não pode, não deve, não ousa expressar”. Para Teixeira (2005), trata-se de um editorial meio às avessas, pois às vezes se coloca contra a seriedade que marca o tom e a escrita do próprio jornal onde se expressa, equilibrando, com sua "loucura", o "excesso" de razão que marca a comunicação contemporânea em geral. Nery (2001) procura aproximar as charges da crônica jornalística moderna, posto que também evidenciam uma relação imaginária e sintética do intelectual com o contexto urbano que o cerca e com a própria linguagem.

2 Informação do jornal Estado de Minas. Disponível em: https://www.em.com.br/app/noticia/ gerais/2019/01/27/interna_gerais,1025145/profundidade-de-rejeitos-em-brumadinho-podechegar-a-ate-15-metros.shtml. Acesso em: 30 out. 2019. 
A teoria semiolinguística de análise do discurso, concebida por Patrick Charaudeau (1992; 1995; 2009), dá destaque às funções dos diferentes sujeitos nos atos de linguagem e, ao mesmo tempo, mantém uma base linguística que apoia suas interpretações. Propõe-se uma abordagem do texto que desvende os sentidos pretendidos por seu enunciador, com a premissa de que a linguagem é mobilizada por sujeitos concretos e historicamente situados, que protagonizam atos comunicativos manifestos em textos por meio dos quais semiotizam o mundo.

Diferentemente de outras vertentes de análise do discurso, a semiolinguística confere aos sujeitos um papel central na teoria, atribuindo-lhes uma intencionalidade que os impele a se colocarem na chamada mise-en-scène discursiva. O sujeito concebido aqui empreende conscientemente uma aposta em direção ao outro, lançando mão dos diferentes recursos disponíveis na língua em prol de estratégias elaboradas para alcançar seus objetivos na troca. Ele se torna autor e responsável pelo seu dizer, embora possa sofrer influências do meio social e cultural.

Na perspectiva semiolinguística, enquanto gêneros textuais, as charges integram o projeto de fala de um enunciador midiático, que representa a chamada instância de produção, a qual, por sua vez, se dirige a uma instância de recepção. O enunciador midiático é movido por duas visadas enunciativas interdependentes: a visada de informação, presente em todo texto de natureza midiática; e também a visada predominante de captação, ligada ao interesse em despertar o interlocutor/leitor para aquilo que é dito (CHARAUDEAU, 2010).

A finalidade do contrato midiático é, portanto, relatar o que ocorre no espaço público, articulando as visadas destinadas a informar - ou fazer-saber - e captar - ou fazer-sentir. Contudo, a charge pende para a captação, cujo objetivo é expressar afetividade para interessar o receptor. Assim, o chargista constrói uma dramatização, na qual se percebem projeções de imagens cristalizadas capazes de despertar efeitos discursivos patêmicos ${ }^{3}$ ou humorísticos, por exemplo, naquele que se informa. Os efeitos de sentido pretendidos pelo enunciador de textos como as charges podem, assim, ser mapeados na materialidade textual através das escolhas verbais e não verbais empreendidas por ele na estrutura de seu discurso.

Apesar de, na maioria das vezes, constituírem-se de uma única imagem, as charges, sendo um gênero de história em quadrinhos, podem ser consideradas narrativas verbo-visuais. Dessa forma, a seguir, serão apresentadas algumas características da construção narrativa dos quadrinhos, com destaque para a expressão do tempo.

\section{A arte de contar histórias por meio dos quadrinhos}

Escrita e imagem são "companheiras" no ato de contar histórias. Ciça Fittipaldi, reconhecida ilustradora de livros infantojuvenis, descreve que

3 O termo pathos, herdado da retórica clássica, em semiolinguística, refere-se à dimensão das emoções como efeitos discursivos de captação do interlocutor nos textos. 
[t]oda imagem tem alguma história para contar. Essa é a natureza narrativa da imagem. Suas figurações e até mesmo formas abstratas abrem espaço para o pensamento elaborar, fabular, fantasiar. [...] Se ao olharmos uma imagem podemos perceber o acontecimento em ação, o estado representado, uma ou mais personagens "em devir", podemos imaginar também um (ou mais) “antes" e um (ou mais) “depois”. E isso é uma narração (FITIPALDI, 2008, p. 103).

Vergueiro (2012, p. 32) aponta que a imagem desenhada (linguagem visual, icônica) é o elemento básico das histórias em quadrinhos, pois ela aparece como uma sequência de quadros que trazem uma mensagem ao leitor, normalmente narrativa. Nas histórias em quadrinhos, a imagem é fixa. O leitor é quem dará dinamismo à história, por meio da sua imaginação e de suas experiências, evocando seus saberes de crença e de conhecimento. Segundo Eisner (2005, p. 75-76), "a menos que os leitores de quadrinhos sejam capazes de reconhecer as imagens ou fornecer os eventos necessários que a disposição das imagens propõe, nenhuma comunicação é estabelecida".

A menor unidade narrativa de uma história em quadrinhos é a vinheta (ou quadrinho). Vergueiro (2012, p. 35) define vinheta como "a representação, por meio de uma imagem fixa, de um instante específico ou de uma sequência interligada de instantes, que são essenciais para a compreensão de uma determinada ação ou acontecimento". Além disso, em um mesmo quadrinho, podem estar expressos vários momentos que, vistos em conjunto, dão a ideia de uma sensação específica.

Para formar a cena, vários elementos ajudam a compor a história e a fazer progredir a narrativa, dando a noção de passagem de tempo dentro dos quadros. De acordo com Campos e Lomboglia (1984, p. 14), alguns dos principais elementos são: o balão, a representação do movimento, a gestualidade, a onomatopeia e a legenda. Com relação aos balões, Quella-Guyot (1994, p. 12) destaca que os diálogos, além de terem por certo a função de caracterizar os personagens ou fazer avançar a ação, apresentam um duplo papel: informar outro personagem (circuito interno da narrativa) e o leitor (circuito externo da narrativa).

Nos termos da semiolinguística, as histórias em quadrinhos articulam dois espaços de significação: um espaço externo ao texto e um espaço interno ao texto. O espaço extratextual é aquele onde se encontram os dois parceiros da troca linguageira: o autor (sujeito comunicante) e o leitor/espectador real (sujeito interpretante); tal interação se dá no universo situacional ou no "mundo real". Entre os espaços externo e interno, estão o narrador (contador da história) e o leitor idealizado (sujeito destinatário). O espaço intratextual, por sua vez, é aquele onde se encontram os personagens - também sujeitos enunciadores e destinatários que imitam o mundo real ou representam um mundo imaginado e interagem entre si no interior da própria obra; esta interação ocorre no universo discursivo, no mundo da ficção. 
Como faz notar Quella-Guyot (1994, p. 102), as histórias em quadrinhos levam o leitor a recriar o movimento a partir de dados gráficos, algo que se tornou um elemento indispensável da HQ. A ilusão e a impressão de movimento são importantes para os quadrinhos na medida em que esse dinamismo impulsiona também a expressão do tempo. A representação do movimento é um recurso utilizado para sugerir a velocidade, a trajetória dos objetos, tremor, espaço percorrido etc. A gestualidade é a representação das expressões faciais e corporais que podem definir o estado de espírito, os movimentos, a personalidade do personagem etc. Tal recurso deve se espelhar nos próprios gestos humanos, para que sejam compreensíveis ao leitor. Postema (2018, p. 48) aponta que a linguagem corporal traz o significado do tempo ao sugerir movimentos anteriores e posteriores à cena representada: algo aconteceu para alguém chorar, alguém partiu para que alguém acenasse etc.

As onomatopeias, nas histórias em quadrinhos, não são simples representações sonoras, elas se transformam graficamente naquilo que descrevem. De acordo com McCloud (2008, p. 146-147), as onomatopeias dão a chance ao leitor de "ouvir com os olhos" e podem representar: o volume, o timbre, a associação com a fonte do som ou a interação gráfica da forma com a imagem a que se vincula. Já as legendas, recurso muito utilizado em todos os gêneros em quadrinhos, aparecem geralmente em pequenos quadros para indicar passagem de tempo ou mudança de local em que transcorre a ação, para dar resumo de uma cena anterior, ou transmitir comentários do narrador. O tempo é um elemento muito importante nos quadrinhos. Segundo Eisner (1989, p. 28), "a habilidade de expressar a passagem do tempo é decisiva para o sucesso de uma narrativa visual”.

Cagnin (2014, p. 61) explica que nos quadrinhos (ocidentais) uma sequência de leitura passa por três tempos: é presente o que está sendo lido; é passado o da esquerda, que já foi lido, é futuro o da direita, que vai ser lido. Assim, a passagem de tempo nos quadrinhos é expressa, geralmente, pela quantidade de quadros utilizados para expressar uma sucessão de ações - quanto maior o número de quadros, maior a sensação de prolongamento do tempo. Conforme foi mencionado anteriormente, até mesmo uma imagem isolada tem grande potencial de narratividade. No caso específico das charges, fortemente ligadas ao contexto extratextual, "a imagem traz a história à mente, sustenta-a, ilustra-a” (Postema, 2018, p. 43). Por isso, o próximo tópico discutirá como se dá a expressão do tempo no gênero que constituirá o corpus de análise deste trabalho.

\section{A expressão do tempo nas charges}

A noção de tempo, embora nos pareça clara por seus efeitos sobre nós, não é uma categoria que se deixa facilmente teorizar. Segundo Henrique (2013, p. 93-4), é uma experiência ambivalente para o homem: envolve, ao mesmo tempo, a consciência de uma categoria objetiva, que atravessa a realidade do mundo sensível, e a experiência da subjetividade, como um modo afetivo de apreensão da realidade. Por essa ambivalência, o tempo assume uma versão simbólica nos discursos, que 
não obstante a consciência de seu fluxo constante e de sua irrepetibilidade, insistem em apreendê-lo, medi-lo e semiotizá-lo através das mais diversas linguagens.

Sob a perspectiva dos filósofos Aristóteles (385-322 a. C.) e Santo Agostinho (354-430), o tempo implica, respectivamente, movimento e continuidade indissociados, e uma relação com a alma humana como medida legítima de sua apreensão mais concreta (HenriQue, 2013). Tais concepções filosóficas nos auxiliam na compreensão da temporalidade como algo que ganha corpo pelo viés do discurso, entendido como memória presentificada. Segundo Santaella e Nöth (1998, p.85), "a capacidade simbólica, que nos é dada pela linguagem, transcende o espaço e tempo biológicos, criando novos padrões, os padrões de significados”. A experiência simbólica temporal, mediada pela linguagem, estabelece, pois, a dimensão sociológica do tempo, sob cuja perspectiva não é nem fluxo objetivo da natureza, nem experiência puramente subjetiva do indivíduo, mas função organizadora da vida social (HENRIQUe, 2013, p. 107).

Aumont (1995) considera que apenas algumas imagens são passíveis de exprimir, de forma "convincente", a dimensão temporal. É o caso das imagens de filmes e vídeos, chamadas temporalizadas pelo autor, por serem dotadas, em sua existência, dos meios de expressão da sucessividade e da linearidade que caracterizam o tempo. Já as imagens bidimensionais, como as pinturas e fotografias, são consideradas não temporalizadas, tendo em vista as restrições da sua materialidade fixa. Entretanto, o autor salienta que as imagens não temporalizadas dispõem de recursos para sugerir a categoria do tempo mesmo de modo secundário. É o que explica a adaptação de recursos da linguagem do cinema pelas HQs, segundo Barbieri (2017), que procura justamente driblar os obstáculos à criação da ilusão do tempo e do movimento no suporte de papel.

Recorrendo, portanto, à sequencialização de quadros, traços de movimento, efeitos de vaporosidade, representações icônicas (como calendários, relógios etc.), repetições de uma mesma imagem, legendas e balões de fala, os artistas gráficos que trabalham com material impresso ou bidimensional, como os chargistas, conseguem imprimir a duração de um instante - ou timing, para Eisner (2010) - em uma cena imóvel, extrapolando seus limites. Convém lembrar, com Aumont (1995), que a construção do tempo de uma imagem e de uma imagem no tempo envolve três aspectos: sua instância enunciativa e os limites de natureza temporal que lhe impõe a arte em que é traduzida; seu caráter como signo de uma realidade temporal que lhe serve de referente; e também sua instância receptora, que interage com a imagem de maneira física, cognitiva e afetiva, sendo responsável por desvelar os efeitos de sentido nela escondidos.

Segundo McCloud (2005), o que permite caracterizar as HQs como arte sequencial é sua progressão em diferentes quadros - traço não intrínseco às charges, uma vez que, normalmente, traduzem-se em imagens fixas únicas. O tempo é, pois, representado em um direcionamento visual da esquerda para a direita (pelo menos no mundo ocidental), que emite uma concepção humana espacial 
sobre seu fluxo. Entretanto, o autor ressalta que, por mais que o quadro seja um indicador geral de uma divisão no tempo ou espaço de textos como as HQs e que sua forma incida sobre nossa percepção dessas categorias, a duração do tempo e as dimensões do espaço são definidas mais pelo conteúdo do quadro do que pelo quadro em si (McCloud, 2005). Portanto, é preciso um diálogo entre aspectos icônicos, plásticos e linguísticos para descrever, como propomos, a representação do tempo nas charges.

Observa-se, pois, que as charges podem manipular os limites do tempo em sua inerente fixidez a fim de melhor retratar determinado fato ou situação de maneira mais expressiva. Ao selecionarmos o corpus deste trabalho, procuramos identificar, então, marcas verbais e não verbais que configuram essa intenção, o que procuramos evidenciar no exame das peças escolhidas, a seguir.

\section{Driblando a fixidez da charge: críticas que se propagam no tempo}

As charges são capazes de transmitir múltiplas informações de maneira condensada (Romualdo, 20oo, p. 17). Desse modo, apesar de aparentemente serem de fácil leitura, todos os mínimos detalhes contribuem para a construção do significado. Geralmente, nas tiras e gibis, há uma não identificação com relação ao tempo. Apesar de frequentemente obedecerem a uma sequência cronológica de revista em revista ou de jornal em jornal e a passagem de tempo poder ser observada no desenrolar das ações, a situação no tempo é imprecisa e não há tempo marcado; há somente expressões genéricas como, por exemplo, "no dia seguinte", "na sexta-feira", "dez anos depois", inscritas em legendas ou na fala das personagens. Tal recurso é utilizado para tornar os quadrinhos atemporais, podendo ser lidos em qualquer época.

Contudo, as charges costumam satirizar fatos atuais que normalmente saem nos noticiários. Elas recriam o fato de forma ficcional, estabelecendo com a notícia uma relação intertextual (RAmos, 2010, p. 21). Por isso, a expressão do tempo é bem demarcada e a passagem do tempo muitas vezes se estabelece no âmbito situacional, fora do espaço interno ao texto. As peças que nos servem nesse estudo tematizam um acontecimento bastante replicado na mídia jornalística impressa, televisiva e nas redes sociais: o rompimento da barragem da mineradora Vale, em Brumadinho (MG), ocorrido em 25 de janeiro de 2019. O acidente, que devastou a cidade mineira, deixando 252 mortos e 18 desaparecidos - a maioria funcionários da empresa -, causou comoção nacional e internacional, tendo sido considerado o maior acidente de trabalho já registrado no Brasil. ${ }^{4}$ Até a data da publicação deste artigo, as buscas ainda têm ocorrido no local. Segundo o site Notícias UOL, os bombeiros vasculham uma área de aproximadamente 4 milhões de metros quadrados e o monitoramento é feito 24 horas por dia. Vejamos o primeiro exemplo,

4 Informações do site Notícias UOL. Disponível em: https://noticias.uol.com.br/cotidiano/ultimasnoticias/2019/10/19/mais-um-corpo-e-encontrado-em-brumadinho-apos-tragedia-da-vale.htm. Acesso em: 30 out. 2019. 
criado pelo cartunista Ferrugem e publicado em seu perfil na rede social Twitter, no dia 25 de janeiro de 2019:

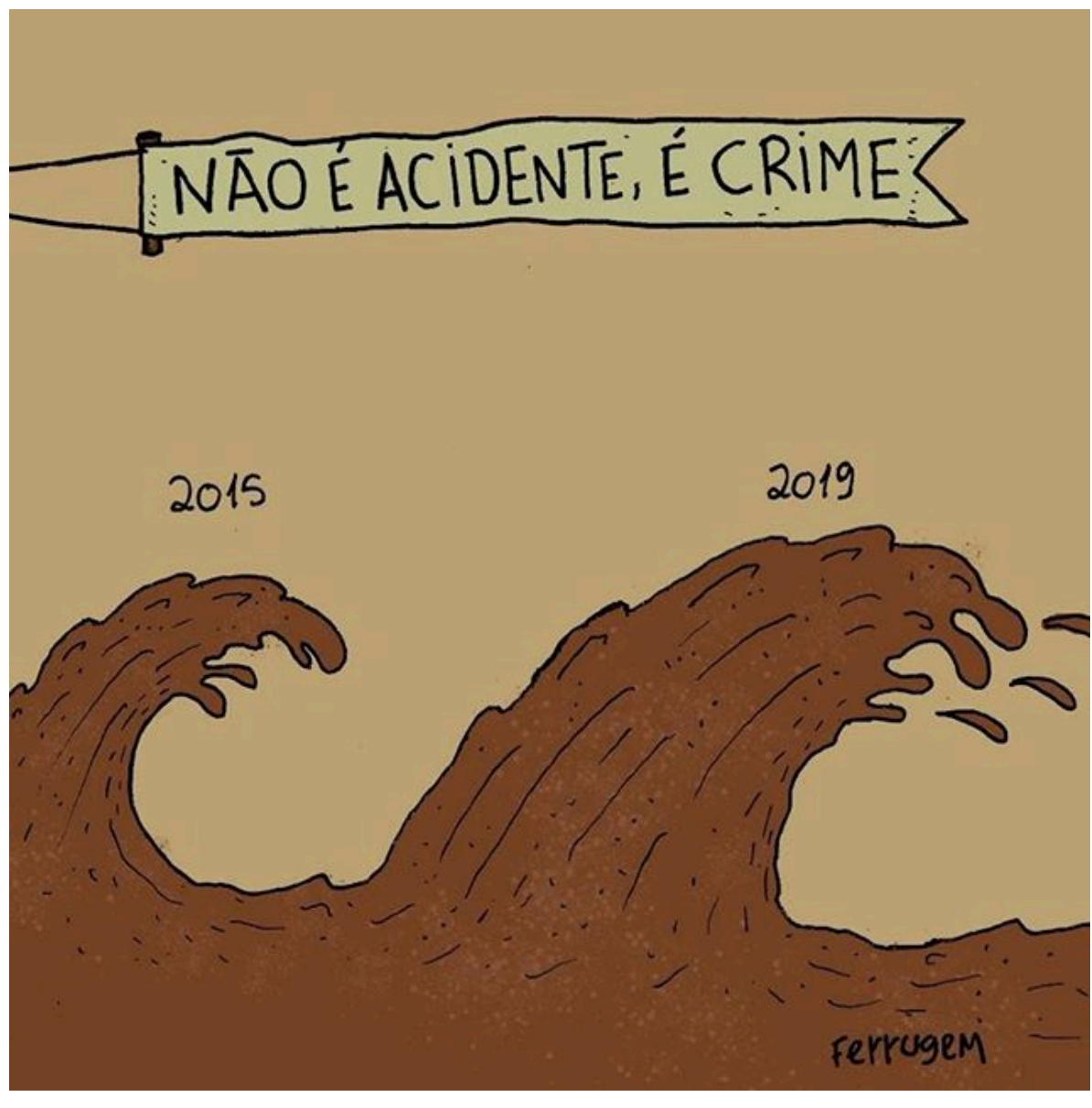

ChARge $1-$ É crime. ${ }^{5}$

Visualmente, a charge se estrutura em torno de uma cena com fundo opaco e indistinto e, em primeiro plano, um mar de lama formando duas ondas que se destacam por sua altura. Na parcela verbal, há a legenda disposta em uma faixa, que diz "Não é acidente, é crime", o que leva o leitor a interpretar os dizeres e as datas e visualizar a lama, ativando seu conhecimento de mundo para se reportar às duas épocas. Ferrugem nos remete, pois, à descrição do rompimento da barragem pela grande mídia e também pela própria mineradora Vale como um "acidente". Em seu ponto de vista, o ocorrido se configura como um "crime", passando a ter fundo intencional e responsáveis culpados.

A referência espaço-temporal é ancorada, portanto, na legenda, bem como na menção aos anos de 2015 e 2019, que nomeiam as ondas do mar de lama em desta-

5 Fonte: https://twitter.com/ferrugemcartune/status/1088894999608127494. Acesso em: 24 abr. 2019 
que na cena. Os anos citados são marcos temporais do rompimento de barragens de rejeitos de mineradoras no Brasil nas cidades de Mariana, ocorrida em 5 de novembro de $2015,{ }^{6}$ e Brumadinho, respectivamente. Na representação de Ferrugem, as ondas de lama ilustram a enxurrada de rejeitos de minério que, de fato, devastou as duas cidades mineiras atingidas. Os signos icônicos e cromáticos associados à parcela verbal do texto dão ideia de movimento e conduzem o leitor a interpretar não apenas o intervalo de quase quatro anos entre as duas tragédias, mas a ligação entre elas. Segundo Wolf (apud PostemA, 2018, p. 48), uma imagem incorpora códigos narrativos e temporais de diversas formas. A primeira charge é um exemplo do que o autor chama de imagem multifásica, aquela em que se incluem diversas cenas distintas de uma mesma história ou em que se apresentam mais do que um momento no tempo dentro do seu espaço.

Além das cores e contornos que se configuram como signos não verbais, vale notar a diferença de tamanho das duas ondas, com ênfase a de 2019, que representa um maior volume da enxurrada de lama para o caso de Brumadinho, potencialmente mais mortal que a de Mariana. É interessante ressaltar que, no entanto, de acordo com o jornal Brasil de Fato, ${ }^{7}$ o volume de rejeitos de Brumadinho foi 50 vezes menor do que o da barragem do Fundão, em Mariana, de modo que a representação de uma quantidade de lama maior em Brumadinho se deve, provavelmente, à maior perda humana - mais de dez vezes maior do que a do desastre ambiental de 2015 .

Esse aspecto visual crescente será explorado também pelo gaúcho Iotti, autor desta peça publicada no portal de notícias GaúchaZH, em 25 de janeiro de 2019.

Vejamos que a construção do cenário da CHARGE 2 é a mesma explorada por Ferrugem: um fundo de cor sombria e sem detalhamento - aqui, salpicado de pequenas manchas claras e escuras, que dão uma ideia de efervescência à correnteza de lama - e o enquadre da enxurrada em primeiro plano, reiterada, dessa vez, em dois quadros. A referência às cidades atingidas pelo vazamento de rejeitos é feita verbalmente por meio de placas, preenchidas na cor amarela, que se destaca entre a sobriedade e tristeza do cinza e do marrom, chamando a atenção do leitor. A legenda "um raio não cai duas vezes no mesmo lugar" constrói a referência de tempo, enfatizando que a repetição da tragédia de Mariana em Brumadinho seria algo logicamente imprevisível. O diálogo com o conhecimento do senso comum, sintetizado nesse adágio popular, reforça expressivamente o ponto de vista do enunciador, que questiona o caráter "acidental" do fato ocorrido. Com efeito, a fala da personagem inserida na segunda cena, respondendo à legenda inicial, reforça a ideia de que sim, no Brasil, uma mesma tragédia ocorreu duas vezes.

\footnotetext{
6 O rompimento da barragem de rejeitos de minério da empresa Samarco em Mariana deixou 19 mortos, sem falar nos inúmeros prejuízos ambientais à região.

7 Disponível em: https://www.brasildefato.com.br/2019/o1/31/raio-x-dos-crimes-umcomparativo-entre-os-impactos-de-brumadinho-e-mariana/. Acesso em: 24 abr. 2019.

8 Fonte: https://gauchazh.clicrbs.com.br/opiniao/iotti/noticia/2019/o1/iotti-coincidenciacjrcnaskdooj2o1ny61qcbicf.html. Acesso em: 24 abr. 2019
} 


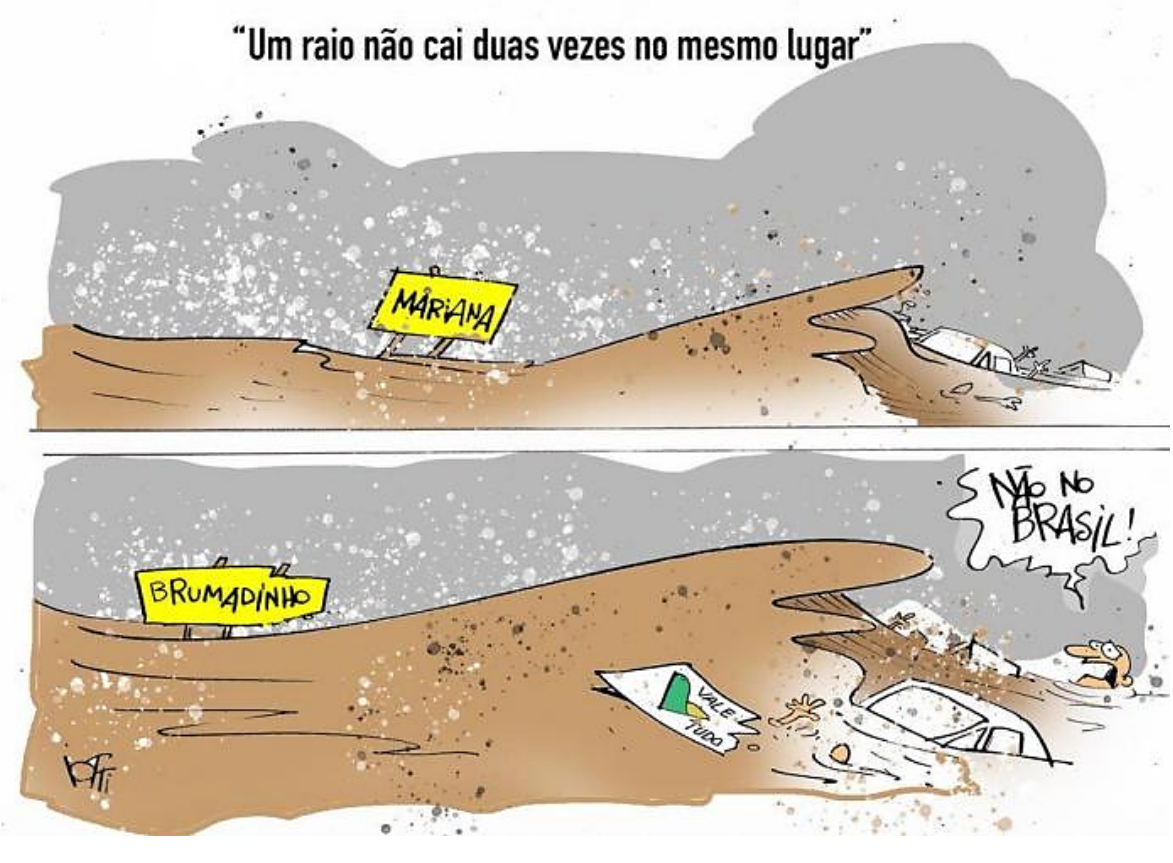

Charge $2-$ Coincidência? $^{8}$

A opção por dois quadros amplia a ideia de temporalidade na charge, estimulando o leitor a preencher o espaço da sarjeta com o tão pequeno intervalo de tempo entre os dois eventos citados, praticamente idênticos, à exceção da intensidade e proximidade com que são descritos: a cena descrita na parte superior parece menor e, consequentemente, mais distante no tempo em relação ao leitor, ao passo que, na imagem da parte inferior, os destroços levados pela correnteza de lama nos parecem mais volumosos e recentes, a despeito de sua menor dimensão real, como já citamos. Além disso, apenas na segunda cena há a presença humana, o que provavelmente foi motivado pela intenção do chargista de enfatizar o maior número de mortos da tragédia ambiental de Brumadinho em comparação com a de Mariana. A comparação de imagens com poucas diferenças, que serviu como mote aos cartunistas Ferrugem e Iotti, também orientou o mineiro Lute nesta peça publicada no jornal Hoje em dia, em 26 de janeiro de 2019.

O enquadre de Lute nos lembra o de uma câmera aérea, que dá uma dimensão mais geral da representação gráfica das cidades de Mariana e de Brumadinho. Vejamos que a construção idêntica das duas cenas dessa vez serve à referência aos passatempos de sete erros, geralmente disponibilizados nos jornais, nos quais o leitor deve identificar as diferenças entre duas imagens quase iguais. Lute omite, então, o maior volume da lama que atingiu a cidade de Mariana e também a maior perda humana que acometeu Brumadinho a fim de ressaltar o que os dois eventos dramáticos têm em comum: erros de empresários e governos implicados na manutenção das mineradoras no Brasil. 


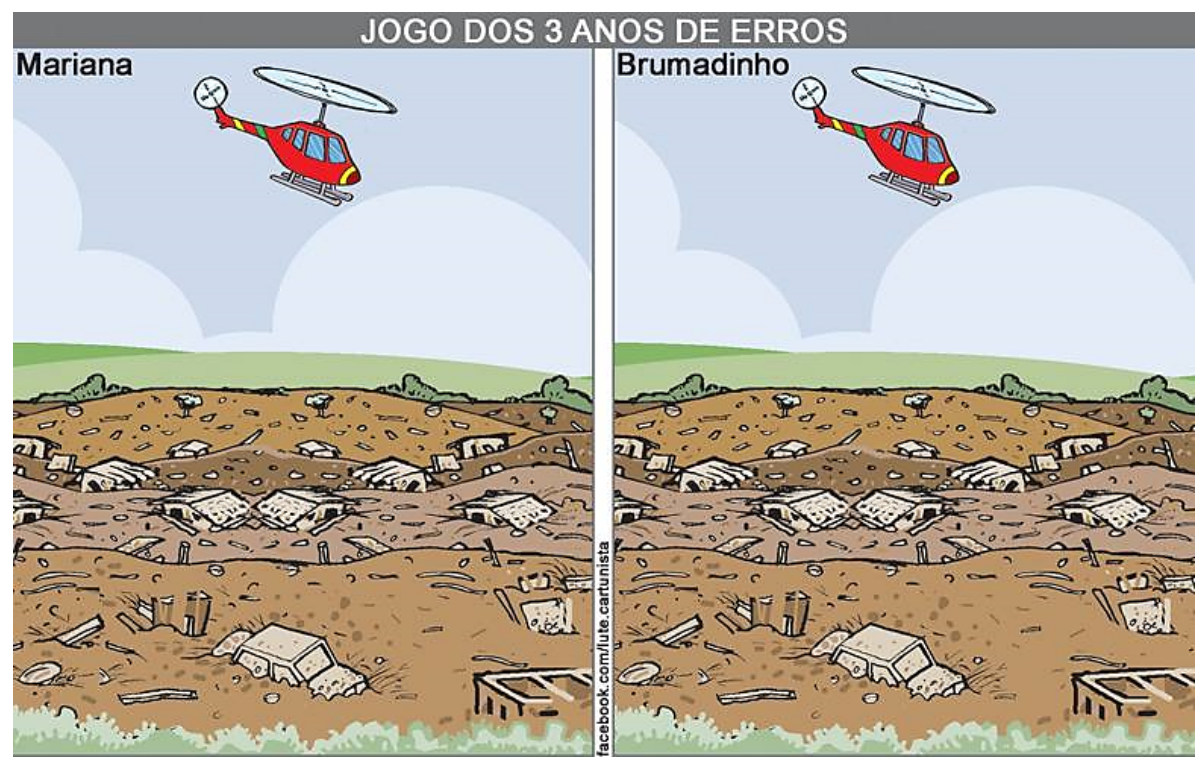

ChARge 3 - Charge do dia 26/o1/2019. ${ }^{9}$

A referência temporal da CHARge 3 é feita, portanto, verbalmente, por meio da legenda "Jogo dos três anos de erros", com ênfase ao pequeno espaço de tempo que separa o rompimento das barragens do Fundão, em Mariana, e do Córrego do Feijão, em Brumadinho; bem como pela referência verbal às duas cidades, que acionam o conhecimento de mundo do leitor no mesmo sentido. A imagem complementa a referência temporal verbal, salientando a grande cobertura de lama, que deixa ver parte do que um dia foram as casas e a vegetação dos locais atingidos pelos rejeitos. Nesta outra peça de Lute, publicada no mesmo veículo, em 25 de abril de 2019, mantém-se a repetição da mesma cena, com progressão temporal ancorada na fala do personagem (CHARgE 4 ).

Aqui, Lute dá ênfase à situação de Brumadinho, novamente ilustrada sob uma vista panorâmica da devastação. As marcas temporais, integradas à fala de um personagem que observa a cena do alto de uma colina, delineiam um movimento para trás e para frente: fazem uma remissão deprimida à tragédia que completa três meses e também empreendem uma projeção hiperbólica para o futuro, salientando que a perda foi tão profunda, que levará "três séculos" para ser superada.

O contraste temporal de três meses e três séculos é corroborado, ainda, pela construção visual da charge, que repete a mesma cena, com predominância da lama suplantando o verde tão famoso da paisagem mineira. Salienta-se, assim, o quão complexa e morosa será a recuperação da cidade. Vale lembrar o emprego da palavra "cicatrizar" em referência a esse processo, que descreve o fato ocorrido

9 Fonte: https://www.hojeemdia.com.br/opini\% $\mathrm{C}_{3} \% \mathrm{~A}_{3} / \mathrm{blogs} / \mathrm{blog}$-do-lute-1.366314?id=1.688987. 1548458458\&title $=$ Charge\%2odo\%2odia\%2026/o1/2019. Acesso em: 27 abr. 2019 

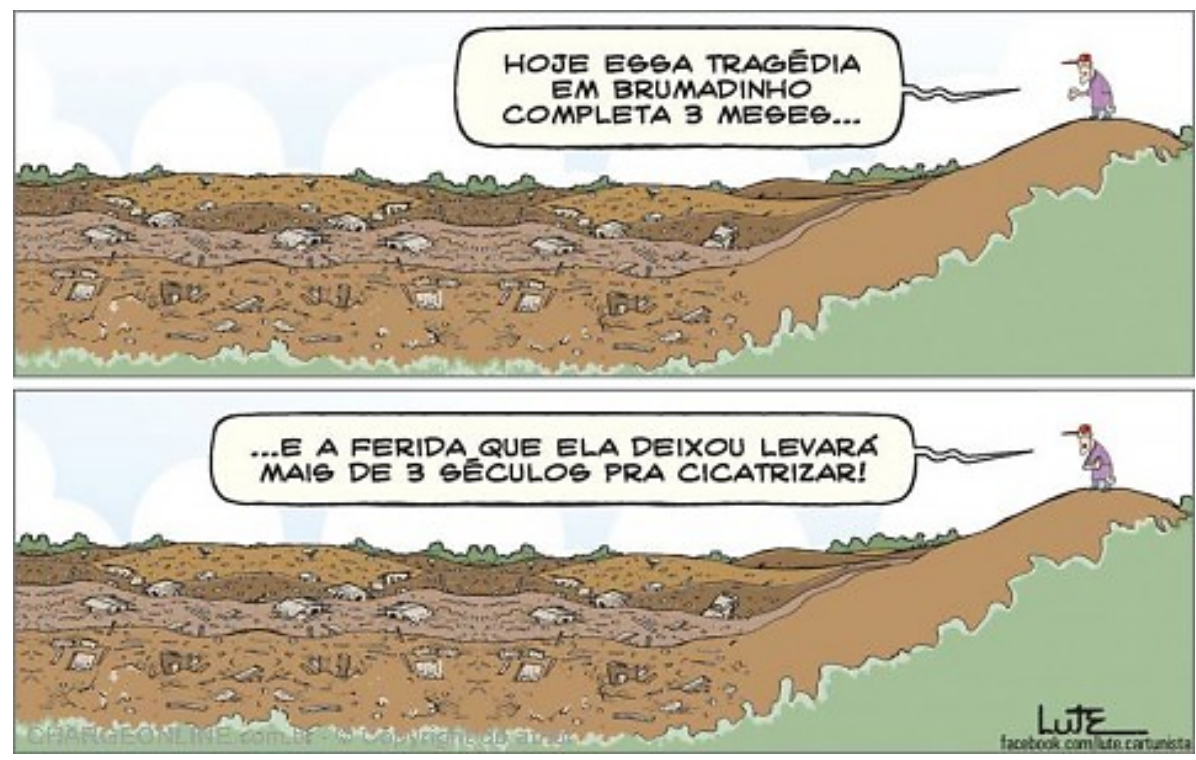

ChARge $4-$ Charge do dia 25/04/2019. ${ }^{10}$

como uma ferida aberta, pressupondo rompimento, dor e sangue, uma metáfora para tantas perdas humanas e ambientais resultantes do rompimento da barragem da Vale. É mais um recurso que exprime a temporalidade, pois uma ferida só cicatriza com o tempo. O paulista Luiz Fernando Cazo também explora ironicamente a ideia de repetição, retratando da seguinte forma o desastre ambiental de Brumadinho, no fornal da economia online, em 31 de janeiro de 2019 (CHARGE 5).

O cenário da charge é composto por dois personagens em meio à lama que predomina no cenário pós-rompimento da barragem do Córrego do Feijão, em Brumadinho. A gestualidade e aparência dos personagens pressupõem que eles foram atingidos pela lama, expressando, assim, temporalidade; além disso, a posição do primeiro rapaz insinua que ele achou dentro da lama o papel que está em sua mão. Nessa charge, Cazo faz brincadeira com um meme ${ }^{12}$ que ficou famoso em 2018: "É verdade esse bilete". O meme surgiu após um menino de 5 anos do interior de São Paulo tentar enganar a mãe com um bilhete falso, com caligrafia infantil, em que disse que não haveria aula. Ele assinou como se fosse a professora e, no fim, para confirmar, dizia: "é verdade esse bilete". Tal meme foi amplamente replicado nas redes sociais, parodiado diversas vezes, aparecendo até mesmo em textos publicitários.

10 Fonte: https://www.hojeemdia.com.br/opini\%C3\%A3o/blogs/blog-do-lute-1.366314/charge-dodia-25-04-2019-1.709778. Acesso em: 26 abr. 2019.

12 De acordo com Fontanella (2009), coloquialmente, os memes são entendidos como ideias, brincadeiras, jogos, piadas ou comportamentos que se espalham na rede virtual por meio de sua replicação de forma viral, caracterizados pela repetição de um modelo formal básico a partir do qual as pessoas podem produzir diferentes versões do mesmo meme. 


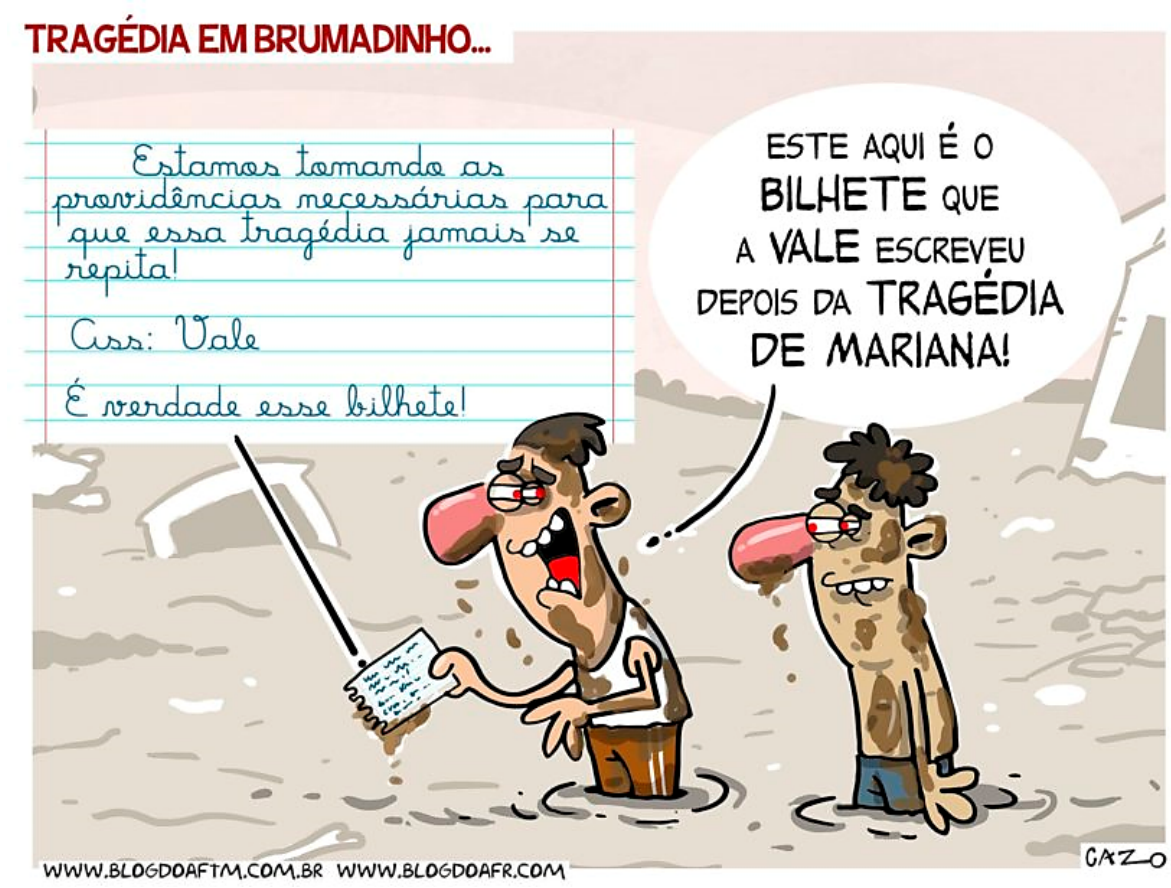

Charge 5 - Tragédia em Brumadinho. ${ }^{11}$

$\mathrm{Na}$ imagem, assim como o bilhete do menino, o tal bilhete da Samarco seria falso, mostrando que o tempo passou e nenhuma providência foi tomada para que a tragédia não se repetisse, ancorando a situação a um evento anterior. O uso do meme traz, portanto, um tom irônico para a charge, pois a Vale, em analogia com o menino da situação original, é qualificada como alguém que queria ludibriar o outro ao escrever o "bilhete". Por meio dessa referência, a CHARGE 5 traz ainda a mesma ideia de associação a um evento semelhante ocorrido anteriormente no tempo, ideia essa que aparece também nas Charges 1 a 4. Finalmente, destacamos a elaboração metafórica bastante expressiva do cartunista cearense Klévisson, nesta charge publicada no jornal Tribuna do Ceará, em 28 de janeiro de 2019 (CHARge 6).

O enfoque de Klévisson tem como base a representação de uma ampulheta, um dos objetos mais antigos empregados para a medida do tempo. Na representação do chargista, a areia que cai do compartimento superior da ampulheta tem o formato e as cores da logomarca da mineradora Vale, responsável pela barragem de Brumadinho e acionista da mineradora Samarco, encarregada da barragem de Mariana. Os grãos coloridos do tempo da empresa caem no compartimento inferior da ampulheta convertidos em lama e caveiras, numa clara referência às muitas vítimas da torrente de rejeitos de minério que devastou as cidades mencionadas, bem como a própria sede da empresa, onde os funcionários faziam suas refeições

\footnotetext{
${ }^{12}$ Fonte: https://jeonline.com.br/noticia/16674/tragedia-em-brumadinho-2. Acesso em: 24 abr. 2019.
} 


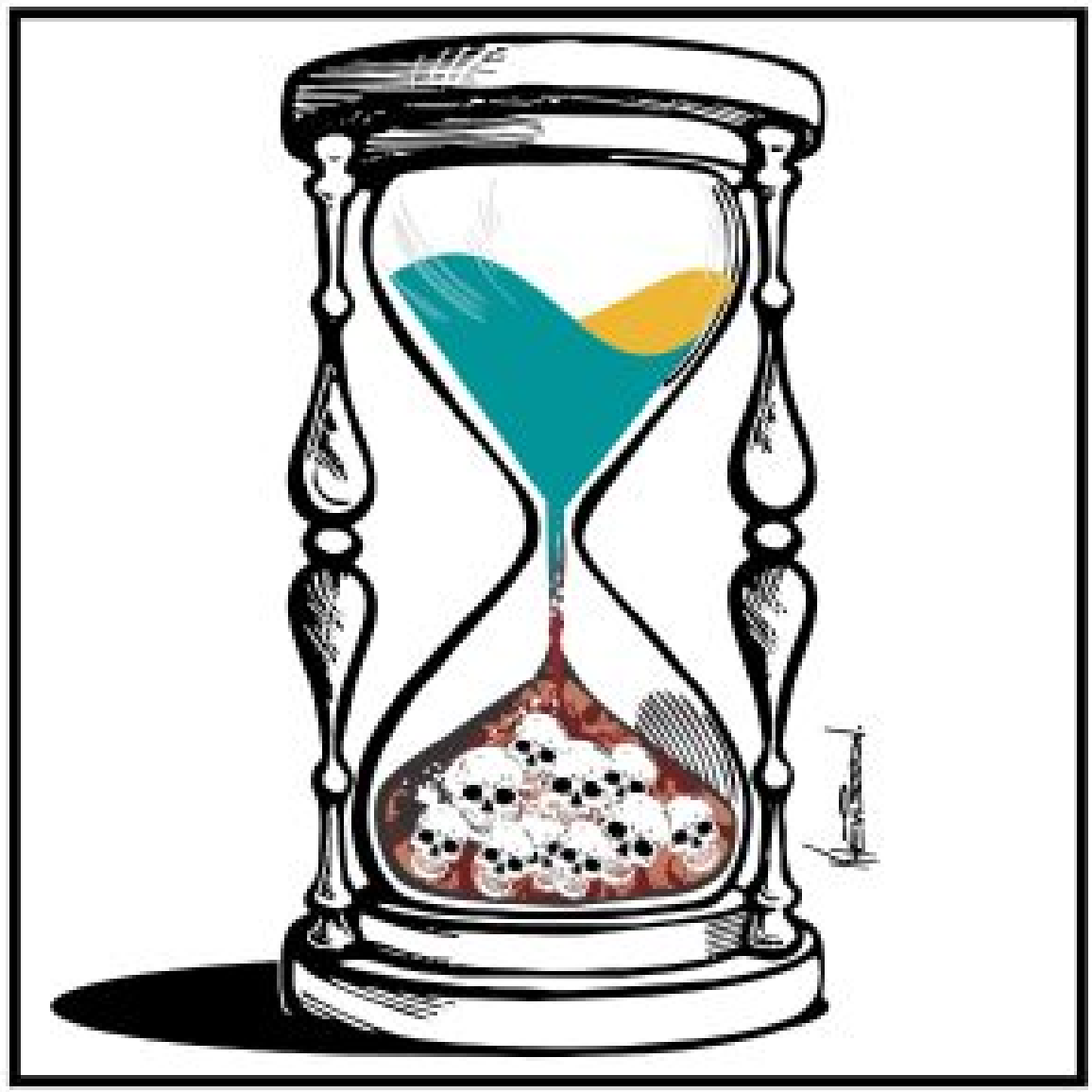

Charge 6 - Ampulheta da morte. ${ }^{13}$

no horário do acidente. A temporalidade da charge é, pois, ancorada apenas nos signos não verbais, que constroem a metáfora visual da ampulheta associada à tragédia ambiental de Brumadinho. Segundo Chinen (2011), as metáforas visuais são uma das invenções mais elaboradas dos quadrinhos, que substituem outras expressões comuns para tornar um conceito mais claro ou exagerá-lo, tal qual as figuras de linguagem.

Sendo assim, na CHARge 6, concluímos que a mineradora Vale, pelo que representa - sua marca - ao longo do tempo, converteu-se em lama e morte não só de centenas de humanos, mas da fauna e da flora da região por onde seus rejeitos passaram. Além disso, como é próprio da contagem do tempo da ampulheta, notamos que a imagem da mineradora aos poucos se extingue nesse rastro sem cor e sem vida, cujo ciclo, ao virar da ampulheta, está destinado a recomeçar.

13 Fonte: http://tribunadoceara.uol.com.br/blogs/nonato-albuquerque/artes/charges-ampulhetada-morte/. Acesso em: 26 abr. 2019. 


\section{Algumas considerações}

Conforme aponta Charaudeau (2009, p. 154), contar representa uma busca constante e infinita da resposta para perguntas fundamentais que o homem se faz: "quem somos? Qual é a nossa origem? Qual é nosso destino?”, ou seja, "Qual é a verdade de nosso ser?”; e como esta não se deixa descobrir, o homem, através de seu imaginário, produz narrativas que, falando de fatos e gestos dos seres humanos, liberam parcelas dessa verdade. Por sua natureza midiática, as charges procuram responder a esse anseio do homem de abarcar a verdade de sua existência. Dedicadas a informar e captar o leitor em seu traço-texto, tais textos expõem uma visão particular dos acontecimentos dignos de nota em um determinado contexto social. A temporalidade da charge é manifesta, assim, no encontro entre signos verbais e visuais, que constituem a sua narrativa, revelando a vivacidade dos quadrinhos como expressão do narrar e atestando a interdependência entre palavra e imagem em seu discurso.

Dentre as seis charges analisadas, cumpre ressaltar que três apresentaram divisão em dois quadros e três foram concebidas como uma única imagem. Com relação às imagens duplas, Postema (2018, p. 51) comenta em sua obra que duas imagens já constituem uma narrativa, pois o significado está inserido na sequencialidade. Com efeito, a fluidez do tempo é construída, nessa estrutura visual dupla, por meio do desdobramento dos acontecimentos em quadros, da repetição de cenas, e de contrastes dimensionais e plásticos, por exemplo. Provoca-se, nesse sentido, o fenômeno da conclusão inferida das sarjetas, que, funcionando como um agente visual de mudança, tempo e movimento por excelência nos quadrinhos, engaja o leitor como colaborador consciente e voluntário na leitura.

Quanto às imagens únicas, seu potencial narrativo é amplificado pela ausência de distração em detalhes desnecessários e até insignificantes; por conseguinte, há uma concentração do significado: qualquer signo visível deve ser considerado como forma significante (Postema, 2018, p. 51-52). Assim sendo, na temporalidade condensada de uma única cena, o cartunista cria dobras temporais, explorando as potencialidades de elementos simbólicos (como traços de movimento e objetos, a exemplo da ampulheta, na ChArge 6) e linguísticos, (como numerais e expressões adverbiais).

Como intentamos mostrar na análise ora empreendida, a temporalidade das charges é um aspecto desse gênero inevitavelmente atravessado pelo olhar subjetivo e pela experiência social da(s) linguagem(ns), que vinculam ao tempo uma dimensão afetiva e simbólica. Em se tratando de um texto que se configura como uma espécie de notícia temperada com a opinião de seu autor, é importante lembrar que o modo de organização narrativo, equilibrando-se entre realidade e ficção, refletirá, sem dúvida, as representações socioculturais que circulam na sociedade na qual o sujeito falante está inserido. 
É assim que a charge consegue condensar e, ao mesmo tempo, expandir a temporalidade que está em sua essência jornalística, sobrevivendo, na memória de seu público, por meio dos efeitos de sentido que visa a provocar com seu traço-texto. Enfim, nas charges, cada elemento é importante para a construção do significado, e o leitor, ao observar a relação estabelecida entre as parcelas verbal e não verbal, precisa utilizar sua imaginação e suas experiências, evocando seus saberes de crença e de conhecimento, para reconhecer os sentidos desse gênero que potencializa informação em um texto tão sintético.

\section{Referências}

Aumont, Jacques. A imagem. Tradução Estela dos Santos Abreu e Cláudio C. Santoro. 2 ed. Campinas, SP: Papirus, 1995.

Barbieri, Daniele. As linguagens dos quadrinhos. Tradução Thiago de Almeida Castor do Amaral. São Paulo: Pieirópolis, 2017.

Barthes, Roland. O óbvio e o obtuso: ensaios críticos III. Tradução Lea Novaes. Rio de Janeiro: Nova fronteira, 1990.

CAgnin, Antonio Luiz. Os quadrinhos: linguagem e semiótica: um estudo abrangente da arte sequencial. 1 ed. São Paulo: Criativo, 2014.

CAmpos, Maria de Fátima Hanaque; Lomboglia, Ruth. HQ: Uma manifestação de arte. In: Luyten, Sonia M. (org.). Histórias em quadrinhos - leitura crítica. São Paulo: Edições Paulinas, 1984.

Charaudeau, Patrick. Grammaire du sens et de l'expression. Paris: Hachette, 1992.

Charaudeau, Patrick. Une analyse sémiolinguistique du discours. In: Langages, 29e année, n¹17, 1995. pp. 96-111. Disponível em: http://www.persee.fr/web/ revues/home/prescript/article/lgge_0458-726x_1995_num_29_117_1708. Acesso em: 10 ago. 2015.

Charaudeau, Patrick. Linguagem e discurso: modos de organização. $1^{\mathrm{a}}$ ed., $1^{\mathrm{a}}$ reimpressão. São Paulo: Contexto, 2009.

Charaudeau, Patrick. Discurso das mídias. Tradução de Angela M. S. Corrêa. 1 ed., $1^{a}$ reimpressão. São Paulo: Contexto, 2010.

Chinen, Nobu. Linguagem HQ: conceitos básicos. 1 ed. São Paulo: Criativo, 2011.

EIsner, Will. Quadrinhos e Arte Sequencial. 4ed. São Paulo: Martins Fontes, 2010.

EISNER, Will. Narrativas Gráficas. São Paulo: Devir, 2005.

FeIjó, Mário. Quadrinhos em ação: um século de história. São Paulo: Moderna, 1997. 
FitTipaldi, Ciça. O que é uma imagem narrativa. In: Oliveira, Ieda (org.). O que é qualidade em ilustração no livro infantil e juvenil: com a palavra o ilustrador. São Paulo: DCL, 2008.

Fontanella, F. O que é um meme na Internet? Proposta para uma problemática da memesfera. In: Simpósio Nacional ABCiber, 3., 2009, São Paulo, Anais. São Paulo, 2009.

Henrique, Beatriz Serrão Petri. Saudades do futuro. Classes de palavras e demarcadores temporais: uma proposta de ampliação conceitual. 2013. 228f. Tese (Doutorado em Letras) - Universidade Federal Fluminense, Instituto de Letras, 2013.

Mccloud, Scott. Desvendando os quadrinhos. Trad. Helcio de Carvalho; Marisa do Nascimento Paro. São Paulo: M. Books do Brasil, 2005.

Mccloud, Scott. Desenhando quadrinhos. São Paulo: M. Books do Brasil, 2008.

Nery, Laura. Charge: a cartilha do mundo imediato. In: Revista Semear. Rio de Janeiro, RJ. Vol 7. 2001. Disponível em: http://www.letras.puc-rio.br/unidades\& nucleos/catedra/revista/7Sem_1o.html. Acesso em: 22 ago. 2015.

Postema, Barbara. Estrutura narrativa nos quadrinhos: construindo sentido a partir de fragmentos. São Paulo: Peirópolis, 2018.

Quella-Guyot, Didier. A história em quadrinhos. São Paulo: Edições Loyola, 1994.

Ramos, Paulo. A leitura dos quadrinhos. São Paulo: Contexto, 2010.

Romualdo, Edson Carlos. Charge jornalística: intertextualidade e polifonia: um estudo de charges da Folha de S. Paulo. Maringá: Eduem, 2000.

Santaella, Lúcia; Nöth, Winfried. Imagem: cognição, semiótica e mídia. São Paulo: Iluminuras, 1998.

Teixeira, Luiz Guilherme Sodré. Sentidos do humor, trapaças da razão: a charge. Rio de Janeiro: Fundação Casa de Rui Barbosa, 2005.

Vergueiro, Waldomiro. A linguagem dos quadrinhos: uma "alfabetização" necessária. In: RAmA, A.; VegueIro, W. (orgs.). Como usar as histórias em quadrinhos na sala de aula. 4 ed. São Paulo: Contexto, 2012. p. 31-64

Recebido em 30 de abril de 2019.

Aprovado em $1^{\circ}$ de novembro de 2019. 


\section{Resumo/Abstract/Resumen}

\section{Tempo e narrativa no gênero charge: condensar para potencializar}

\section{Eveline Coelho Cardoso}

\section{Glayci Kelli Reis da S. Xavier}

O rompimento da barragem construída pela mineradora brasileira Vale, que devastou a cidade de Brumadinho (MG) em janeiro de 2019, é o tema de seis charges que compõem o corpus do presente artigo. Sob a perspectiva de análise do discurso semiolinguística, as charges são gêneros discursivos oriundos de um contrato comunicativo midiático, equilibrado, como tal, entre duas intenções principais: informar e captar o leitor. Driblando, contudo, a objetividade e credibilidade típicas da mídia, as charges narram uma versão pessoal e crítica da realidade, expressa em uma verbo-visualidade "carregada" de opinião, humor e ironia. Veremos, pois, de que maneira tais textos manifestam a temporalidade por meio de mecanismos linguísticos e simbólicos das histórias em quadrinhos, que lhes permitem romper a aparente fixidez de sua estrutura.

Palavras-chave: semiolinguística, história em quadrinhos, charge, tempo, narrativa.

\section{Time and narrative in editorial cartoons: condense to potentialize \\ Eveline Coelho Cardoso}

\section{Glayci Kelli Reis da S. Xavier}

The collapse of the dam built by Vale, a Brazilian mining company, which devastated the city of Brumadinho (MG) in January 2019, is the theme of six editorial cartoons that constitute the corpus of this article. Based on the Semiolinguistic Analysis of Discourse, editorial cartoons are discursive genres derived from a mediatic communicative contract, balanced, as such, between two main intentions: informing and capturing the reader's attention. Circumventing, however, the typical objectivity and credibility of the media, editorial cartoons narrate a personal and critical version of a situation, expressed in a verb-visuality "loaded"with opinion, humour and irony. Thus, we will analyse how these texts express temporality by using linguistic and symbolic mechanisms which are common in comic books, allowing them to break the apparent fixity of their structure.

Keywords: semiolinguistics, comics, editorial cartoons, time, narrative. 


\section{Tiempo y narrativa en el género viñeta: condensar para potenciar}

\section{Eveline Coelho Cardoso}

\section{Glayci Kelli Reis da S. Xavier}

La rotura de la represa construida por la minera brasileña Vale, que devastó la ciudad de Brumadinho (MG) en enero de 2019, es el tema de seis viñetas que componen el corpus de éste artículo. Bajo la perspectiva de análisis del discurso semiolingüístico, las viñetas son géneros discursivos derivados de un contrato comunicativo mediático, equilibrado, como tal, entre dos intenciones principales: informar y captar la atención del lector. Rompiendo, sin embargo, la objetividad y credibilidad características de los medios de comunicación, las viñetas narran una versión personal y crítica de la realidad, expresada en una verbo-visualidad "cargada"de opinión, humor e ironía. Veremos, pues, cómo eses textos manifiestan la temporalidad a través de mecanismos lingüísticos y simbólicos de los cómics, que les permiten romper la aparente fijeza de su estructura.

Palabras clave: semiolingüística, cómics, viñetas, tiempo, narrativa. 